\title{
VERSE MISCELLANIES AND THE CIRCULATION OF A DONNE ELEGY
}

\author{
BY STEPHANIE HUNT
}

Judging by the numbers of extant copies of Donne poems in manuscript, John Donne (1572-1631) may have been the most popular poet of his generation. There are over 4,000 Donne manuscript texts, and the astounding number of manuscripts that survive attest not only to his widespread appeal, but also to the nature of textual circulation in Renaissance England. For certain forms of writing such as lyric poetry, scribal circulation still dominated over print, even more than a century after the printing press was brought to England. ${ }^{1}$ Only three of Donne's poems circulated in print while he lived. Those that circulated in manuscript did so in much greater numbers than the remnants that survive, of which the Donne Elegy in the Rutgers collection (manuscript call number FPR 2247. E37), commonly known by the title "Love's Progress" - though here simply titled "Elegy" - remains a revealing example. The elegy is here collected with another short poem by another author-both remain unnamed-and thus the manuscript provides a telling instance of the circulation of Donne's work in manuscript poetic anthologies. The second poem, here called "Sonett" but elsewhere known by such diverse names as "On a proud maide," "On Women," "A Wife," "Epigram," and "A Catch" has been attributed to Matthew Mainwaring (1561-1652), an author little known to twenty-first century audiences. ${ }^{2}$ Because of their disparities in style and of their respective authors' notoriety, the juxtaposition of the two poems might initially seem eccentric to a twenty-first century reader. I will argue that this juxtaposition provides important insights into the circulation of Donne's work in manuscript poetic anthologies.

Readers of Donne's poetic manuscripts have not taken into account the specific evidence offered by this manuscript. Apart from John Shawcross's mention of the Rutgers manuscript in his 1967 edition of Donne's work and the Variorum edition's inclusion of the manuscript in its catalog of the extant manuscripts of 
"Love's Progress," there is no scholarly discussion of this particular manuscript text. More significantly, catalog accounts of the Rutgers Donne manuscript neglect to mention the companion poem. While the absence of any mention of the companion poem in either Peter Beal's record of the Donne elegy or in the Variorum should not be surprising given these compilers' overriding concern with Donne as an authorial figure, ${ }^{3}$ I would argue that the companion poem and its relationship to Donne's elegy merits serious consideration. This manuscript juxtaposes two poems in a way that is ostensibly indifferent to style, genre, and author in a way that provides evidence to current research in early modern reading practices of lyric poetry. What seems important to the creator of the Rutgers Donne manuscript and the verse miscellany it seems to have been taken from is not form, style, or authorship, but the potential for illicit amusement which their shared thematic contents might have brought. Furthermore, the Rutgers Donne manuscript participates in the tradition of verse miscellanies that proliferated in both manuscript and print during the seventeenth century, which suggests the pervasiveness of the modes of reading that the scribe who produced the manuscript evidently practiced. ${ }^{4}$ Thus, we might also use the Rutgers Donne manuscript to explore further the intersections of print and manuscript miscellanies, and the various uses to which they put Donne's poetry.

Manuscript circulation in the early modern period served many functions beyond the expected sense of material circulated for commentary or correction in preparation for later print publication. Manuscript publication was often an alternative to print, and could take many forms. Authors could take a direct hand in the scribal publication of their works, and indeed it was the preferred mode of circulation for poets like Donne, as well as Sir Philip Sidney, Thomas Traherne, Andrew Marvell, and Katherine Phillips. Scribal publication could be sought over print publication for many reasons, whether to avoid the stigma of print, to preserve a sense of familiarity between author and audience, to evade censorship, or for economic reasons. ${ }^{5}$ Scribal publication could also be undertaken for entrepreneurial purposes, wherein manuscripts would be produced for sale by anyone but the author. This type of manuscript production usually consisted in lavish presentation copies of manuscripts prepared to order or put up for sale readymade. Manuscript production could also take the form of what Harold Love has called "user publication," a form of replication 
undertaken for personal, non-commercial use, usually in the form of personal verse miscellanies or commonplace books, many of them anonymous. ${ }^{6}$ It is this latter form of manuscript production and circulation that concerns us here.

For one thing, it was not uncommon to find Donne's poetry collected into large manuscript volumes and commonplace books, especially after his death. ${ }^{7}$ The incorporation of Donne's poetry into larger collections of verse also displayed a common practice of assembling works according to genre. Donne himself imitated the classical poets by grouping his works into "composite groups of satires, elegies, [and] verse letters." ${ }^{8}$ However, the Rutgers Donne manuscript also strains against this practice of grouping Donne's poetry according to generic and authorial boundaries, particularly because it assembles the elegy with a song reminiscent of the bawdy drinking and ale-house songs and thus does not clearly imitate the elevated classical modes or display a level of learning commensurate with Donne's poem. The manuscript itself is anonymous, and clearly not penned by Donne himself (amazingly given the number of Donne manuscripts that survive, there is only one in Donne's hand that remains, "The Letter to Lady Carey" ${ }^{\prime \prime}$ ). Although it remains as a single sheet of paper, material evidence strongly suggests it is a portion of a longer manuscript verse compilation. Their grouping suggests that the poems' shared emphasis on the degraded aspects of love, and not their form or style, is perhaps what most appealed to the literary tastes of the scribe.

The physical condition of the manuscript reveals that it may have once been part of a bound volume. The handwriting is a rapid, and often quite rough, secretary hand. The spacing between the lines and line lengths are irregular, and there are several inkblots and corrections. The evidence of the hasty transcription indicates the amateur status of the scribe. While the manuscript might have been intended for some limited circulation, it was almost certainly not intended for this circulation as part of a handsome, professionally prepared volume of poetry. The physical condition of the manuscript also indicates it was once part of a larger volume of poetry. It consists of a single sheet, folded in half along the vertical axis, which perhaps indicates a technique for preparing the page before inscription to insure straight margins. There is a horizontal crease across the page's meridian as well, suggesting the possibility that the sheet itself might have belonged to a quarto gathering of blank pages, from which it perhaps had been removed 
according to the scribe's need for paper. In the fold are a number of thread holes indicating the possibility of the manuscript being part of a thread-bound quire. The second half of the page, front and back, remain blank, as if intended for further additions to the manuscript that were not made. We might be able to conclude from this that the manuscript could have been intended for some kind of compilation. Perhaps the leaf survives from a commonplace book that had fallen apart, or it may have been torn apart by an unscrupulous dealer who wanted to get the most money from the sale of separate sheets. We can, however, be confident that the single leaf was part of a larger bound verse miscellany, and that we have at least two of the poems originally set side by side.

The Rutgers Donne manuscript is catalogued in the Variorum edition of Donne's poetry along with the 37 other known extant manuscripts containing both full and partial copies of the Donne's elegy. ${ }^{10}$ The editors argue that there are two major groupings of the manuscripts: the first lineage seems to have been copied from a now lost original holograph; the second from a lost revised holograph. ${ }^{11}$ According to their argument it seems likely that Donne revisited the text to correct an ambiguity in line 27. Fourteen of the manuscripts and the printed copies of the poem found in Robert Chamberlain's The Harmony of the Muses (1654) and John Menness Wit and Drollery $(1656,1661)$ show "Then hee that tooke her mayd," while twentytwo manuscripts and the 1669 collected works of John Donne record "Then if hee tooke her maide."12 The manuscript held at Rutgers falls into this second category of manuscripts copied from the revised version of the poem. However, its idiosyncratic textual variants make the Rutgers Donne manuscript difficult to classify with greater precision. Its relationship to the other extant copies is unclear, and we can only surmise that there are a number of lost intermediate texts from which it descends. ${ }^{13}$ The fact that it is not clearly related to any other of the surviving manuscripts makes it impossible to determine who might have copied it, from what, and the extent of its distribution. The manuscript's physical condition itself leaves us with little evidence for the historical context of its production. Donne scholars speculate that the elegies themselves as a group were most likely composed in the early 1590s, although no specific dates can be determined for their composition. ${ }^{14}$ However, Peter Beal's Index of Literary Manuscript indicates that a number of copies of the poem date from the early 1620 s to the 1630 s, suggesting an impulse to suppress the poem's broader distribution for many years. There is no 
concrete evidence that enables such a precise dating of the Rutgers Donne manuscript, leading Beal to conclude its production in the early seventeenth century. While we may not be able to discern a more direct line of transmission that would more clearly indicate its relationship to other manuscript and print copies of the poem, and while we may not be able to date the manuscript precisely, we can make some other useful inferences. Many, though by no means all, of the manuscript copies of "Love's Progress" are collected as part of a manuscript sequence of Donne elegies, indicating a concern by some seventeenth-century readers for both authorial identity and generic continuity. This manuscript, however, varies markedly from this kind of authorial and generic compilation, opting instead to organize the two poems thematically.

Both poems appeal to a shared sense of humor at women's expense: each posits a male voice addressing other men, expressing solidarity and commiseration that comes from their shared dealings with the opposite sex. ${ }^{15}$ While the "Sonett" expresses sympathy for men saddled with vain women, "Love's Progress" is framed as a set of instructions in the art of seduction delivered by one allegedly experienced in its trials and difficulties. "Loves Progress," through its use of the blazon, charts a course through unknown territory and grafts this map onto the female body, thereby likening global exploration and trade with the pursuit of the "right true end of love" (2), both intercourse and female genitalia, the "centrique part" (36). The poem's exploration of its central conceit results in its graphic and sexually explicit nature, the most apparent reason for the poem's suppression from a wide manuscript distribution and from print. Achsah Guibbory argues that Donne's poem reduces women's value to their genitals, thus denying the value of their beauty, virtue, wit; love's progress, then, is "progressive mastery" over the female's genitals. ${ }^{16}$ Arthur Marotti has also observed that the poem's equation of erotic love with world exploration "unmask[s] the self-serving erotic and avaricious impulses behind cynical libertine attitudes." ${ }^{17}$ Erotic love, libertinism, and economic ambition are inextricably linked in the poem.

The central conceit of the poem thus compares seduction as a "journey of exploration and discovery," but the voyage also produces considerable risk for the less experienced, and may present "potential entrapment for the unwary male." ${ }^{18}$ Yet, the speaker, in guiding the reader through the pitfalls of the progress of love, seems to imagine himself in a similarly perilous journey. The use of 
pronouns throughout the catalog of the female body suggests that the speaker implicates himself directly in the dangers of navigation. Using the third person plural in "How much they stray" (40), the speaker appears to solidly distinguish himself from "they," those who, by undertaking the voyage, are misguided. However, the pronouns shift to the more inclusive first person plural: "The brow becalmes us" (43) and "shipwarcks us againe" (44), "the nose ... directs us" (47-50) and at her lips "we anchor fast and thinke ourselves at home" (54), although this sense of security and having "won" or completed the progress is misplaced. Suddenly, it is not "they" but "us" and "we," a group the speaker includes himself in, that undergoes the hazardous journey.

Compared to the "Sonett" in the manuscript, the central conceit of "Love's Progress" displays a greater sense of ingenuity on Donne's part. It differs from the "Sonett" also in its larger scope, structuring gender relations through the terminology of global trade and market exchanges. Nevertheless, this is not to exclude the possibility that equal amounts of pleasure might have been gained by both poems with their shared concerns for the sexual. As in Donne's poem, the "Sonett" grafts issues of gender onto economic concerns, albeit on a smaller scale. It maps out a domestic space, rather than a global one; where "Love's Progress" associates female intractability with the risks of economic venturing, the "Sonett" conflates issues of wasteful domestic management and female vanity:

She that will eate her breakefast in her bedd And spend the morne in dresinge of her head And sitt at dinner like a mayden-bride And nothing do all day but talke of ride

God in his mercy may do much to save her But what a case is he in that must have her.

The poem is reminiscent of the uncouth "she that ..." verses recited by Iago in Othello:

She that was ever fair, and never proud;

Had tongue at will, and yet was never loud;

Never lack'd gold, and yet went never gay;

Fled from her wish, and yet said "Now I may"...

$(2.1 .146-49)^{19}$ 
which Desdemona scorns as full of "old fond paradoxes to make fools laugh i'th'alehouse" (2.1.137-38).

The poem is furnished with the tokens of a recognizably private space of the home: it begins with a woman in her bedchamber, moves to her dressing room and then to the dinner table (1-3). The emphasis on the woman's self-indulgent activities also descends, into vaguely repulsive bawdry by the end of the poem. The "case" in which the man bound presumably by marriage or some other sexual relationship to such a woman refers most basically to an undesirable situation, it incorporates an erotic pun that suggests "he" finds himself literally "in" her "case." The "case" also suggests a contained space, the tight boundaries of the domestic sphere, implying a kind of claustrophobia that is both literal and figurative. The poem thus ends with an expression of pity for the man forced to endure any kind of sexual engagement with an unreasonable woman and, moreover, forced to contend with the constraints of a domestic life with her. Both poems, then, create a community of men structured by a penchant for the bawdy, a deep mistrust of women, and a concern for the realm of finance which embodies the risk and discomfort that relationships with women might entail, at least in the eyes of the poems' male speakers and (ostensibly) male addressees. Perhaps the poems also link scribe and readers through a shared literary taste defined by their potential for amusement and offense. The fact that the Rutgers Donne manuscript appears as an anonymous poem, paired not with a sequence of Donne elegies but with a simpler and more colloquial poem only loosely tied to Donne's through broadly similar thematic concerns suggests a more complex rubric through which we might consider seventeenth-century understandings of lyric genre and its social uses.

Though it may initially strike us as peculiar that Donne's poem should be paired with this apparently frivolous, ephemeral song in this manuscript, so different in tone, diction and style, further research into the print history of "Love's Progress" reflects how pervasively the apparently elevated nature of Donne's elegies resonated with ostensibly less "dignified" poems for contemporary audience. While elegies are often associated with the mourning and commemoration of the dead, they were not limited to this subject. The Roman elegy referred to any poem written in elegiac couplets (alternating hexameter and pentameter lines) addressing a range of topics, from lovers' laments, to love letters, to letters of advice, to 
denunciations. ${ }^{20}$ In the Renaissance, the elegy was chiefly devoted to the mode of the Petrarchan lament: humanist poets and poetic theorists from Daniel to Drayton to Puttenham associated the genre with its mournful potentials; Donne's use of the mode, however, is quite distinct. ${ }^{21}$ Alan Armstrong remarks that Donne's elegies covey the "irreverent wit and lighthearted cynicism of Ovid." ${ }^{22}$ R.V. Young associates Donne's elegies with the model of the Roman love elegy, generated by Catullus. ${ }^{23}$ Young also argues that the most obvious model for Donne's elegies is Christopher Marlowe's translation of Ovid's Amores under the title Ovid's Elegies, published in 1598, but perhaps known to Donne through manuscript circulation since they would have been completed by Marlowe's death in $1593 .{ }^{24}$ Whatever the model for Donne's work, in writing a sequence of elegies he clearly announces his interventions in the humanist imitation of classical forms which might initially indicate a sharp stylistic distinction from the decidedly more "low-brow" "Sonett" with which it is paired. ${ }^{25}$

What unifies the two poems, however, is their sexually explicit and thoroughly misogynistic natures that belie their shared potential for offense and amusement. Indeed, Donne himself seemed to have fretted over the lewdness of his elegies. A 1600 letter of Donne's to Sir Henry Wotton gives strong indication that the cause of his elegies' suppression from broader circulation may have been embarrassment and fear of repercussions for their sometimes graphically elicit depictions: "to my satyrs there belongs some feare and to some elegies and these [paradoxes included in the letter] perhaps shame." ${ }^{26}$ Scholars speculate that the letter's expressions of shame for the satires and elegies and fear at the prospect of their broader distribution might reflect Donne's concern for his "responsible position" in the employ of the Lord Keeper, and his "growing love for Ann More," whom he married in December $1601 .{ }^{27}$ Further, as R. C. Bald indicates, there was "real danger" in publishing Donne's elegies and love poetry at this time "not merely to his reputation and his prospects, but even his person." ${ }^{28}$ In light of the Essex uprising and Hayward's scandalous dedication to Essex in History of Henry the Fourth, the Archbishop and the Bishop of London began imposing far stricter publication regulations that extended to satires, epigrams, and elegies. Many books had been burnt, including Marvell's translation of Ovid's Elegies, and it seems likely Donne's elegies and satires would have met a similar fate had they too been published. ${ }^{29}$ 
Because of its bawdiness, "Love's Progress" was among the five elegies excluded from initial publications of Donne's collected works. It was most likely withheld from print either by those offended at the sexually explicit nature of the contexts, or by those desirous to protect Donne's reputation since he had become a prominent member of the Anglican clergy. ${ }^{30}$ Although all five elegies were included in the manuscript submitted by John Marriot to the Stationer's Register in 1632, they were allegedly excluded for similar reasons. While two of these excepted elegies were later included in the 1635 edition (but without permission from the Stationer), "Love's Progress" continued to be excluded from Donne editions until 1669.

But the first appearance of the poem in print was not in a collection of Donne's poetry, nor was it collected by any means with other poems that could be considered elegies, which gives further evidence for the fact that a multitude of factors, including thematic concerns and awareness of their potential for light amusement, underlie early modern estimations of lyric poems. It occurred in first in Robert Chamberlain's The Harmony of the Muses: Or, The Gentlemans and Ladies Choisest Recreation; Full of various, pure, and transcendent Wit. Containing several excellent Poems; Some, Fancies of Love, some of Disdain, and all the subjects incident to the passionate Affections either of men or women (1654). Donne is listed on the frontispiece by name (as Dr. Joh. Donn) along with those "unimitable Masters of Learning and Invention," including Henry King, William Stroad, Ben Jonson, Francis Beaumont, Thomas Randolph, and Thomas Carew, and "others of the most refined Wits of those TIMES." Donne's poem is here titled "Loves Progress, by Dr. Don." The 1654 edition also features the elegy conventionally titled "On his mistress going to bed," but we might note that the two poems are not collected sequentially, so authorship and genre, it might be concluded, is not the predominant underlying organizational scheme for the volume. "On his mistress" is also here titled "An elegy made by I.D." We might take note of the distinctions that these two titles make: the volume makes two kinds of authorial attributions (one noting Donne's status in the church, the other opting for initials); it also makes significantly different generic attributions. "Loves Progress" is not explicitly identified as an elegy, while "On His Mistress" is given a generic title that identifies only the poem's genre. This raises the following questions: do the volume's compilers consider "Loves Progress" as an elegy, 
or as something else? Does it reflect a wider impulse amongst seventeenth-century readers to read the poem as something other than an elegy, or to not read the elegies in their entirety as a sequence? Why does the attribution of "Love's Progress" appeal to Donne's respectable position as the dean of St. Paul's, while "On His Mistress Going to Bed" does not? What further conclusions can we draw about how Donne's work is received and how his name is appropriated by these miscellany volumes? The appearance of the poem under various titles and grouped with poems of diverse forms reflects the instability of the generic categories. It also reflects that other modes of reading that determined the selection and organization of verse compilations predominated. The first printed versions of Donne's elegy perhaps reveal that print miscellanies attempted to heighten the prestige and novelty of their volumes by including a Donne poem not available elsewhere in print, and perhaps the compiler of the Rutgers Donne manuscript felt a similar interest in masking the illicit nature of both poems under the guise of elevated learning. Or perhaps these poems simply brought amusement to the miscellany's compiler, and print miscellanies included Donne's poetry to appeal to that market.

The other two print editions in which "Loves Progress" appears, put out by John Mennes in 1656 and in a revised edition in 1661, add further evidence for the interpretive and classificatory impulses of those who appropriated Donne's work. The first edition of Mennes' Wit and Drollery, Jovial poems advertises the novelty of its contents, for it claims to collect poems "Never before printed" (a claim that is, as far as Donne's poem is concerned, demonstrably disingenuous - no doubt for commercial reasons-given its appearance in print two years prior). The elegy appears last in the volume, following a song titled "A resolution not to marry." As with the Rutgers Donne manuscript, the volume could be said to be using a broadly thematic organizational principle in its arrangement of the poems. But the second edition significantly rearranges the volume: Donne's elegy, also titled "Loves Progress" is nestled amongst a series of epigrams on diverse subjects, from poems called "An epilogue upon the honest lawyer," to a series of epigrams on a variety of occupations.

The brief six-line "Sonett" itself seems to have had a fairly wide circulation in the period, albeit to a lesser extent than the widespread circulation of Donne's poetry: the Folger Index of First Lines (which, it should be noted, fails to catalogue its appearance in 
the Rutgers Donne manuscript) lists at least 18 manuscript copies. It was also set to music by John Hilton (1599-1657) in the midseventeenth century. An organist and composer, Hilton was prolific in his production of both religious songs and lighter fare, and was best known as the compiler of Catch that Catch Can (initially published 1652 by John Playford and later expanded in subsequent editions in 1658 and 1663), in which the "Sonett" appears as a round for three voices along with musical notation. ${ }^{31}$ It appears in two other print sources of the seventeenth century: in Wits recreations. Selected from the finest fancies of moderne muses (1640), as "On a proud Mayde"; and again as "On a proud Maid" in John Mennes's Recreation for ingenious head-peeces, or, A pleasant grove for their wits to walk in of epigrams 700, epitaphs 200, fancies a number, fantastick abundance: with their addition, multiplication, and division (1654). The song apparently retained enough longevity to be featured as late as 1733 in the first edition of Benjamin Franklin's Poor Richard's Almanac. We can thus speculate on the popularity of the poem that enabled it to survive a trans-Atlantic circulation, and a circulation that extends across centuries.

Evidently, seventeenth-century readers produced manuscript miscellanies that grouped Donne's elegy with a broad range of poems on diverse subjects and in diverse forms. The proliferation of printed texts that included Donne's elegy alongside poems of a similar nature also suggest that the practice of reading his elegies in this way was so pervasive as to prompt early-modern print houses to take advantage of that market. As philosophically complex and learned as the Donnian elegy might be, early modern readers were also prepared to see it as something also similar in kind to the abounding "wit and drollery" of the occasional, performative, musical, and crass texts typical of the verse miscellany, in both its manuscript and printed formats. Thus, the Rutgers Donne manuscript might prompt us to rethink how we define the seventeenth-century elegy, and even seventeenth-century humanist poetic practices more generally, in the context of its frequent appearances in other verse miscellany of the period. While none of these print versions of the poem have a direct correlation to the Rutgers Donne manuscript (all three descend from the "first lineage" of the poem, while the Rutgers manuscript descends from the second), what they do confirm about the manuscript is the sense in which we might view it as additional evidence for how categories of genre were constructed by seventeenth-century 
readers. The manuscript might also open up investigations into how seventeenth-century compilers of verse and print miscellanies appropriated Donne's work and Donne's notoriety for various ends. The poem's frequent grouping with poetic genres most often associated with Cavalier poets and with Royalist allegiances reflects certain political uses of Donne's work long after his death that perhaps deserve more critical attention.

\section{Notes}

1. See Peter Beal, Index of Literary Manuscripts, vol. 1 (London: Mansell, 1980) 244-49, and "John Donne and the Circulation of Manuscripts," in The Cambridge History of the Book in Britain, John Barnard and D. F. McKenzie, eds., vol. 1 (Cambridge: Cambridge UP, 1999-): 122-26.

2. The Oxford Dictionary of National Biography identifies Mainwaring as the author of a loose translation of a Catalonian romance entitled Vienna (licensed and first published in 1628, an evidently popular enough to merit two reprintings in 1632 and 1650), H. G. C. Matthew and Brian Harrison, eds., vol. 36 (Oxford, New York: Oxford UP, 2004), 176. Unfortunately the unusually long-lived Matthew Mainwaring, who has been attributed as the author won't be of assistance to us in narrowing down the date of the poem's original composition, and thus won't allow us to provide a more precise date for the manuscript itself.

3. See Beal, 244-49 and Gary A. Stringer, et. al., eds. The Variorum Edition of the Poetry of John Donne, Volume 2: The Elegies (Bloomington and Indianapolis: Indiana UP, 2000), 301-31.

4. Adam Smyth has thoroughly discussed the print verse miscellany, an immensely popular type of publication that compiled an eccentric range of poems, usually unattributed or misattributed, and often set in Royalist or courtly frames. See "Printed Miscellanies in England, 1640-1682: 'Store-Houses of Wit,'" Criticism 42, no. 2 (Spring 2000): 151-84.

5. See J. W. Saunders, "The Stigma of Print: A Note on the Social Bases of Tudor Poetry," Essays in Criticism 1 (1951): 139-64; see also Thomas Fulton, Historical Milton: Manuscript, Print, and Political Culture in Revolutionary England (Amherst: U of Massachusetts P, 2010) 15-37; Heidi Brayman Hackel, Reading Material in Early Modern England (Cambridge: Cambridge UP, 2005), 17-43. 
6. For discussion of these broad categories of manuscript circulation, see Harold Love, "'Publication' in the Scribal Medium," Scribal Publication in Seventeenth-Century England (Oxford: Clarendon, 1993) 35v89; see also Margaret Ezell, Social Authorship and the Advent of Print (Baltimore: Johns Hopkins UP, 1999), pp. 1-60, Peter Beal, In Praise of Scribes: Manuscripts and their Makers in SeventeenthCentury England (Oxford: Clarendon, 1998).

7. Love, p. 51.

8. Ibid.

9. Nicholas Barker, "Donne's 'Letter to Lady Carey and Mrs. Essex Riche," in Form and Meaning in the History of the Book (London: British Library, 2003), 7-14.

10. Variorum vol. 2, p. 304. See also Robin Robins, ed. The Complete Poems of John Donne (Harlow, England: Longman, 2010) 347-48 for a concise textual history of the poem.

11. Variorum vol. 2, p. 305.

12. Ibid.

13. Ibid., p. 310.

14. See "Dates and Circumstances" in the Variorum vol. 2, 448-53.

15. Indeed, the fact that the "Sonett" was set to music for multiple voices also reflects the polyvocal and collaborative nature of the poem (see discussion of print sources for the text below).

16. Achsah Guibbory, "'Oh, Let Me Not Serve So': The Politics of Love in Donne's Elegies," ELH 57 (1990): 819. See also Alvin Sullivan, "Donne's Sophistry and Certain Renaissance Books of Logic and Rhetoric," Studies in English Literature, 1500-1900 22 (1983), 115-16, and Terry G. Sherwood, Fulfilling the Circle: A Study of John Donne's Thought (Toronto: U of Toronto P, 1984), 72-73, which also observe that poem reduces women's value to mere sexual pleasure.

17. John Donne: Coterie Poet (Madison and London: U of Wisconsin P, 1986), 51.

18. Guibbory, "Oh, Let Me Not Serve So," 818.

19. William Shakespeare, Othello, ed. Michael Neill (Oxford: Oxford UP, 2006). Subsequent citations are taken from this edition.

20. See Robins, The Complete Poems, 287-88 for succinct definition of the elegy.

21. Robins, The Complete Poems, 287.

22. Alan Armstrong "The Apprenticeship of John Donne: Ovid and the Elegies." ELH 44 (1977): 419. 
23. "The Elegy," The Oxford Handbook of John Donne, eds. Jeanne Shami, Dennis Flynn, and M. Thomas Hester (Oxford: Oxford UP, 2011) 135.

24. Young, 136.

25. For further discussion of other aspects of humanist learning reflected in the poem, particular scholastic modes of argumentation and the influence of an intense training in rhetoric and logic see also Patrick Cruttwell, "The Metaphysical Poets and Their Readers" Humanities Association Review 28 (1977) and Alvin Sullivan, "Donne's Sophistry and Certain Renaissance Books of Logic and Rhetoric," Studies in English Literature, 1500-1900 22 (1983).

26. John Donne: Selected Prose, eds. E. M. Simpson et. al., (Oxford: Clarendon, 1967), 111. Given the date posited by E. M. Simpson, the letter most likely belongs to that grouping of correspondences centered around the disgrace of Essex in late 1599-1600. Claude Saunders and Ted-Larry Pebworth argue that, given that the letter self-consciously turns away from court life and from the political tensions which preoccupied it and instead turns to concerns of Donne's literary reputation, it probably more specifically dates from late 1600 after Wotton, a sometime supporter of Essex, had retired briefly from political life and abandoned his allegiances to Essex. "Donne's Correspondence with Wotton," John Donne Journal 10 (1991): 3, 25.

27. A Study of the Prose Works of John Donne (Oxford: Clarendon, 1948), 317.

28. R.C. Bald, John Donne: A Life (New York and Oxford: Oxford UP, 1970), 121.

29. See Bald, John Donne, 121-22.

30. Ted-Larry Pebworth, "The Censorship of John Donne's Elegies and Sapho to Philaenies in Mansucript and Print," Text: An Interdiciplinary Annual of Textual Studies 13 (2000): 194. For further information on the print publication of the elegies, and its effects on their grouping as a sequence, see also Gary A. Stringer, "Evidence for an Authorial Sequence in Donne's Elegies," Texte: An Interdiciplinary Annual of Textual Studies 13 (2000): 175-92.

31. Oxford Dictionary of National Biography, vol. 27, 245. 